\title{
Facts about Riboflavin ${ }^{1}$
}

\author{
R. Elaine Turner ${ }^{2}$
}

\section{Why do we need riboflavin?}

Riboflavin is one of the B vitamins. It also is known as vitamin $B_{2}$. We need riboflavin to use the carbohydrates, fats, and proteins in the foods we eat. Riboflavin helps us use these nutrients for energy in our bodies. Riboflavin also is needed to properly use the vitamins niacin, folate, and vitamin $\mathrm{B}_{6}$.

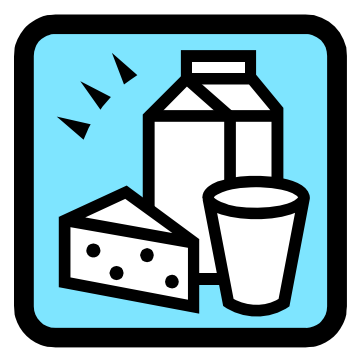

\section{What happens if we don't get enough riboflavin?}

Because riboflavin is found in a variety of foods, most people get plenty in their diets. A

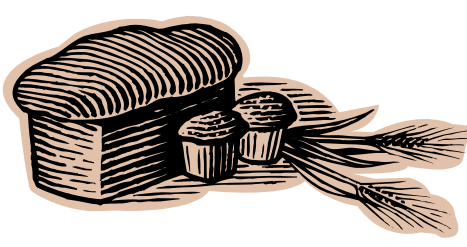

$$
\begin{aligned}
& \text { deficiency of } \\
& \text { riboflavin occurs } \\
& \text { only when the diet is } \\
& \text { very poor, and lacks } \\
& \text { many nutrients. }
\end{aligned}
$$

A lack of riboflavin causes sores in the mouth and inflammation of the tongue. Lack of riboflavin also can affect the body's use of other vitamins.

\section{How much riboflavin do we need?}

The following table lists recommended daily intakes of riboflavin:

\begin{tabular}{||l|c|}
\hline \multicolumn{1}{|c|}{ Life Stage } & \multicolumn{1}{|c|}{$\begin{array}{c}\text { Riboflavin } \\
\text { (mg/day) }\end{array}$} \\
\hline Men, ages 19+ & 1.3 \\
\hline Women, ages 19+ & 1.1 \\
\hline Pregnancy & 1.4 \\
\hline Breastfeeding & 1.6 \\
\hline mg = milligrams \\
\hline
\end{tabular}

\section{How can we get enough riboflavin?}

Milk and milk products are good sources of riboflavin. Riboflavin also is found in whole grains.

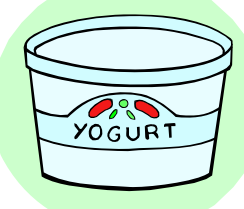

Riboflavin is one of four vitamins added to enriched grain products such as enriched flour. The other vitamins added to enriched grains are thiamin, niacin, and folic acid.

1. This document is FCS8668, one of a series of the Department of Family, Youth and Community Sciences, Florida Cooperative Extension Service, Institute of Food and Agricultural Sciences, University of Florida. First published: June 2001. Revised: August 2006. Please visit the EDIS Web site at http://edis.ifas.ufl.edu

2. R. Elaine Turner, PhD, RD, Food Science and Human Nutrition Department, Cooperative Extension Service, Institute of Food and Agricultural Sciences, University of Florida, Gainesville, 32611. 
Enriched breads and cereals contain riboflavin. Look for the word "riboflavin" in the ingredient list on the label to see if it has been added.

INGREDIENTS: Enriched
semolina (iron, thiamin
mononitrate, folic acid,
riboflavin, niacin), tomato, beet
and spinach powders, ...

Other good sources of riboflavin are: Meat, eggs, and mushrooms.
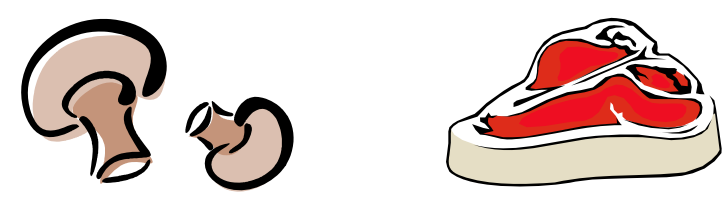

Here are some foods and the amount of riboflavin they contain:

\begin{tabular}{||l|c|}
\hline \multicolumn{1}{|c|}{ Food } & $\begin{array}{c}\text { Riboflavin } \\
\text { (mg per } \\
\text { serving) }\end{array}$ \\
\hline Yogurt, 8 oz & 0.5 \\
\hline Milk, 1 cup & 0.4 \\
\hline Ready-to-eat cereal, 1 cup & 0.4 \\
\hline Egg, cooked, 1 large & 0.3 \\
\hline Pork chop, cooked, 3 oz & 0.3 \\
\hline Mushrooms, cooked, 1/2 cup & 0.2 \\
\hline Cottage cheese, 1/2 cup & 0.2 \\
\hline $\begin{array}{l}\text { mg = milligrams } \\
\text { oz = ounces }\end{array}$ \\
\hline
\end{tabular}

\section{How should foods be prepared to retain riboflavin?}

Riboflavin is easily destroyed when exposed to light. Milk stored in glass and exposed to light loses much of its riboflavin content. Opaque plastic jugs and paper cartons protect the riboflavin in milk. Only small amounts of riboflavin are lost in cooking.

\section{What about supplements?}

Most people get plenty of riboflavin in their diet, so supplements usually are not needed. Most multivitamin supplements contain riboflavin.

Research has not yet found problems from consuming too much riboflavin from food or supplements. However, there is

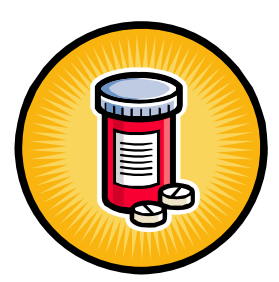
no need to take a supplement with more than 100 to $150 \%$ of the Daily Value for riboflavin.

\section{Where can I get more information?}

The Family and Consumer Sciences (FCS) agent at your county Extension office may have more written information and nutrition classes for you to attend. Also, a registered dietitian (RD) can provide reliable information to you.

Reliable nutrition information may be found on the Internet at the following sites:

http://fycs.ifas.ufl.edu

http://www.eatright.org http://www.nutrition.gov

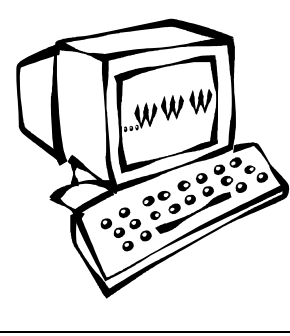

